\title{
The Impact of Auditor Changes on CEO Compensation
}

\author{
Yinghong Zhang ${ }^{1}$ \\ ${ }^{1}$ Lally School of Management, Rensselaer Polytechnic Institute, USA \\ Correspondence: Yinghong Zhang, Lally School of Management, Rensselaer Polytechnic Institute, Troy, New \\ York, NY 12180, USA. Tel: 1-518-276-2342. E-mail: zhangy22@rpi.edu
}

Received: October 11, 2013

Accepted: November 8, $2013 \quad$ Online Published: December 23, 2013

doi:10.5539/ijef.v6n1p1

URL: http://dx.doi.org/10.5539/ijef.v6n1p1

\begin{abstract}
In this study, I investigate whether auditors are a good external control mechanism to restrain management from intentionally increasing CEO compensation through earnings management. To examine this, I regress variations of CEO cash and total compensation on changes in auditors after controlling financial, stock market, industry and year variables. There are two sample periods. In the period 1993-2004, I examine the impacts of overall auditor changes and auditor changes that are classified by the audit failure or auditor brand names. In the period 2000-2004, I check the influences of auditor resignations and of auditor dismissals due to accounting disagreements.

The empirical results show that changes in cash compensation is positively related to the existence of auditor changes and this relationship actually comes from auditor changes from big 5 auditors to non-big 5 auditors. Meanwhile, changes in total compensation is negatively associated with the appearance of auditor switches from non-big 5 auditors to big 5 auditors. These findings are consistent with the notion that big 5 auditors are more active at discouraging earnings management. Overall speaking, the empirical evidences support my belief that auditors do not function very well to monitor managers' opportunistic behaviors.
\end{abstract}

Keywords: CEO compensation, cash compensation, total compensation, auditor changes, auditor resignations

\section{Introduction}

Literature about executive compensation documents a common phenomenon that CEOs manage earnings to increase their compensation (Gaver, Gaver, \& Austin, 1995; Holthausen, Larcker, \& Sloan, 1995; Gaver \& Gaver, 1998; Balsam, 1998; Bergstresser \& Philippon, 2004; etc.). According to the agency cost theory, this happens when incentives of agents do not align with those of principals (Jensen \& Meckling, 1976; Holmstrom, 1979). Strong corporate governance, as the internal control mechanism, can discourage management's behaviors of receiving extra compensation that is not related to pay-for-performance measures (Core, Holthausen, \& Larcker, 1999). This study investigates whether auditors, as the external control mechanism, are effective at monitoring management's actions of increasing compensation through earnings management.

Auditors, working as the "public watchdog", should realize that their client is board of directors, the representative of shareholders, not management (POB, 2003). Nevertheless, besides the monitoring role, auditors also have the responsibility of providing timely and useful information (signaling role) and the responsibility of complying with legal and regulatory requirements (insuring role) (Wallace, 1987). In some cases, auditors do not consider the monitoring role their primary responsibility. These cases occur partly because shareholders are not required to vote on auditor selection before the effectiveness of the Sarbanes-Oxley Act (Raghunandan, 2003; Raghunandan \& Rama, 2003; Krishnan \& Ye, 2005). Therefore, managers of some companies have decision powers to choose auditors and those auditors are more likely to allow managers to manipulate earnings to a certain degree.

Bradshaw, Richardson and Sloan (2001) show that the higher the levels of accruals, the more likely auditors will issue standard audit opinions. Although the level of discretionary accruals is the increasing function of the probability of a GAAP violation, a high probability of a GAAP violation is not necessary for auditors to issue modified opinions (Bradshaw et al., 2001). DeFond and Subramanyam (1998) further indicate that auditors' preference for conservative accounting choices is not based on the desire to control earnings management but the desire to avoid future litigation, i.e. the impairment of the insuring role. Therefore, as long as the extent of discretionary accounting choices does not bring the threat of litigation to auditors, auditors are not willing to 
persuade managers to adjust their accounting treatments.

This study investigates whether auditor changes affect auditors' willingness to allow managers to inflate earnings through discretionary accruals to increase compensation. To my knowledge, my study is the first to directly establish the relationship between CEO compensation and auditor changes.

In my study, I examine variations of CEO compensation based on changes in auditors after controlling influences of firm size, investment opportunity set, firm performance, firm risk, industries and years. My sample period is 1993-2004 (including years before the passage of Sarbanes-Oxley Act and the transition year for the enactment of Sarbanes-Oxley Act) when I investigate impacts of overall auditor changes and auditor changes that are classified by the audit failure or brand names. This sample period is further limited to 2000-2004 when I check influences of auditor resignations and auditor dismissals due to accounting disagreements.

I identify a positive relationship between CEO cash compensation and the incidence of auditor changes. Further analysis suggests that this positive relationship comes from the auditor changes from big 5 auditors to non-big 5 auditors. These results indicate that due to a larger probability of facing the litigation exposure, big 5 auditors are stricter than non-big 5 auditors to restrain managers' opportunistic behaviors of overstating earnings. This argument is further supported by the empirical result that CEOs receive less total compensation after auditors are switched from non-big 5 auditors to big 5 auditors.

In summary, my findings present some evidences that auditors do not act as a good constraint to managerial discretion of increasing compensation through accounting choices. Auditors' monitoring ability is different across auditor brand names. This study is important because the Sarbanes-Oxley Act has changed the rule for auditor selection. Section 301 requires the audit committee to be "directly responsible for the appointment, compensation, and oversight of the work of the auditor". Consequently, auditors should be more independent and impose more weight on their monitoring role relative to other two roles. Auditors should have largely discouraged managers' behaviors of manipulating earnings and there should be no relation between CEO compensation and changes in audit information. Therefore, this study confirms the usefulness of Section 301, Sarbanes-Oxley Act by providing evidences that auditors are not so capable of performing their monitoring role before the issuance of the Sarbanes-Oxley Act (SOX) and the transition year of implementing SOX.

This study contributes to the compensation literature by bringing auditing information to predict CEO compensation. This study also contributes to the auditing literature by testing whether auditors function well as the external control mechanism to monitor management's opportunistic behaviors. My study especially benefits the literature of auditor changes by showing that compensation concern is one additional reason for managers to switch auditors.

The next section provides the review of compensation and auditing literature. Section III discusses the development of hypotheses. In section IV, I present the regression models. Section V illustrates the sample selection. Section VI offers an analysis of auditor changes along the sample years. In Section VII, I discuss the OLS regression results. I summarize and conclude in Section VIII.

\section{Literature Review}

\subsection{Compensation and Accounting Earnings}

The agency cost theory states that the utility functions of the principal and the agent are disparate (Jensen \& Meckling, 1976). Thus if there is a conflict between the interests of shareholders and management, the inherent moral hazard problem occurs because management desires at maximizing their own welfare (Jensen \& Meckling, 1976; Holmstrom, 1979). If executives' wealth is dependent on accounting earnings, executives are motivated to manipulate earnings to receive higher compensation (Gaver, Gaver, \& Austin, 1995; Holthausen, Larcker, \& Sloan, 1995; Gaver \& Gaver, 1998; Balsam, 1998; Bergstresser \& Philippon, 2004; etc.).

Since compensation is tied to accounting gains but not losses (Gaver \& Gaver, 1998), executives are more likely to report positive earnings instead of negative earnings. They achieve this by overstating discretionary accruals because discretionary accruals, especially positive discretionary accruals, enhance the compensation level (Balsam, 1998). Actually, accounting accruals have increased dramatically since 1980 (Bergstresser \& Philippon, 2004).

In addition, earnings management happens in contract settings where the benefits dominate the costs (Gaver et al., 1995; Balsam, 1998). The conflict with auditors is one type of costs (Balsam, 1998).

\subsection{Auditor as the External Control Mechanism}

The responsibility of auditors is to provide assurance that information contained in financial statements is in 
conformity with GAAP. Thus auditors are ultimately responsible for financial statement users, especially shareholders, but not management (POB, 2003; Gibbins, Salterio, \& Webb, 2001). Since agency cost is used to monitor agent from impairing the welfare of the principal (Jensen \& Meckling, 1976), audit cost is one type of agency costs and auditors are one external control mechanism for management (Wallace, 1987).

Previous studies have showed the relation between corporate governance, as the internal control mechanism, and executive compensation. In general, weaker corporate governance are associated with greater level of compensation (Core, Holthausen, \& Larcker, 1999) and compensation contracts emphasizing incentive compensation, especially accounting-based performance measures (Harvey \& Shrieves, 2001; Davila \& Penalva, 2004).

Reported earnings are the joint outcome of negotiations between executives and auditors (Antle \& Nalebuff, 1991; DeFond \& Subramanyam, 1998; Gibbins et al., 2001). Seeking for positive earnings, managers tend to hide income overstatements and protest against income understatements (Antle \& Nalebuff, 1991). To the opposite, auditors prefer conservative accounting choices, namely, the immediate recognition of expenses and the delay of revenues, to avoid potential legal complaints from investors (DeFond \& Subramanyam, 1998). If there is a conflict between auditors and managers, auditors will offer some revisions to managers. Managers can accept revisions to receive standard reports, reject revisions to receive non-standard opinions, request auditors to perform an extended audit, or dismiss the incumbent auditors. Auditors can either choose to extend the audit or resign from the engagement after perceiving that the risk is too high (Antle \& Nalebuff, 1991; Gibbins et al., 2001).

The monitoring role of auditors may be impaired because reported earnings may not reliably and relevantly reflect firm performance. First, the degrees of conservatism vary among auditors (Krishnan, 1994; Hackenbrack \& Nelson, 1996; DeFond \& Subramanyam, 1998). Second, management and auditors have different private information so that auditors are not able to detect income overstatement intentionally hidden by management (Zimbleman \& Waller, 1999; Gibbins et al., 2001). Third, auditors make compromises to management because they are not independent. The independences of auditors is threatened due to the affiliation of auditors with the client (Menon \& Williams, 2004; Lennox, 2005) and non-audit services (Frankel, Johnson, \& Nelson, 2002; Chen, Krishnan, \& Su, 2002). Fourth, auditors come up with false conclusion due to the stress of deadlines or changes in auditing standards (Gibbins et al., 2001).

Before the effectiveness of the Sarbanes-Oxley Act, managers have the powers to appoint auditors and the shareholder ratification on auditor selection is not mandatory (Raghunandan, 2003; Raghunandan \& Rama, 2003; Krishnan \& Ye, 2005). In fact, even shareholders choose to vote on auditor selection, the percentage of voting against the auditor appointment is very low (Raghunandan \& Rama, 2003) (Note 1). Therefore, managers are able to choose auditors who do not function efficiently regarding the monitoring role.

\subsection{Auditor Changes}

Auditor changes are provoked not by management's seek for favorable audit opinions but by auditors' conservative applications of financial standards (Krishnan, 1994). Since the successor auditor is less conservative than the predecessor auditor, discretionary accruals in the first year after auditor switches are less income decreasing than the prior years (DeFond \& Subramanyam, 1998).

Economic characteristics also change along with auditor switches. Roberts, Glezen and Jones (1990) imply that companies, which change auditors, have lower audit fees, weaker internal controls, and smaller likelihood of complying with laws and regulations than companies, which do not change auditors. Dhaliwal, Schatzberg and Trombley (1993) show that compared to auditor changes without disagreements, auditor changes with disagreements are associated with poorer earnings performance, more debts, lower levels of current assets, and poorer stock performance.

Relevant studies are Francis and Wilson (1988), DeFond (1992) and DeFond and Jiambalvo (1993) that examine the association of auditor changes with variables representing agency costs or compensation. Francis and Wilson (1988) indicate that agency cost proxies as a group are tied to auditor "brand name", namely, big eight versus non-eight auditors. DeFond (1992) discovers short-term accruals, a proxy for agency costs, is negatively related to audit quality. This is inconsistent with his hypothesis and he assigns this result to differences in risk tolerances across auditors. DeFond and Jiambalvo (1993) test two possible factors, debt and compensation arrangement, related to auditor-client disagreement. They find that disagreement firms experience a decline in earnings, which is consistent with the belief that firms disassociate with incumbent auditors because earnings are too low. However, DeFond and Jiambalvo (1993) do not directly examine the relationship between executive compensation and auditor-client disagreements. 


\section{Hypothesis}

The demand for auditing comes from the desire to monitor management shirking if there are information asymmetries between managers and owners (Jensen \& Meckling, 1976). Thus auditors act as the external control mechanism to management. However, sometimes auditors do not function well to deter managers' opportunistic behaviors. This phenomenon happens because: 1) some auditors are less conservative about the appropriate application of GAAP (DeFond, 1992: Krishnan, 1994; Hackenbrack \& Nelson, 1996; DeFond \& Subramanyam, 1998), 2) new auditors have less private information about the client so that managers are able to hide earnings inflation (Zimbleman \& Waller, 1999; Gibbins et al., 2001), 3) auditors have the economic bond with the client because the client hires former audit staff (Menon \& Williams, 2004; Lennox, 2005) or purchase non-audit services (Frankel, Johnson, \& Nelson, 2002; Chen, Krishnan, \& Su, 2002).

Therefore, if managers are not satisfied with the GAAP treatments of their incumbent auditors, they are inclined to be associated with other auditors who are less conservative, know less about the firm-specific information, or are economically tied to them. They are able to do so because they have the decision power to select auditors and shareholders rarely vote against their decisions (Raghunandan, 2003; Raghunandan \& Rama, 2003; Krishnan \& Ye, 2005). Consequently, if the compensation contract is based on accounting measures and the contract structure has not been changed, managers are able to overstate discretionary accruals (DeFond, 1992; DeFond \& Jiambalvo, 1993; DeFond \& Subramanyam, 1998). Consequently, executive compensation is intentionally increased (Gaver, Gaver, \& Austin, 1995; Holthausen, Larcker, \& Sloan, 1995; Gaver \& Gaver, 1998; Balsam, 1998; Bergstresser \& Philippon, 2004; etc.). This leads to the first hypothesis:

\section{H1: Compensation becomes higher after the firm changes the auditor.}

However, the relation between compensation and auditor changes varies depending on the public announcement of audit failure, auditor brand names, and types of auditor switches. In the following, I develop specific hypotheses about auditor changes.

Due to the accounting failure of Enron, investors perceive audits of other Arthur Andersen clients to be of lower quality (Chaney \& Phillipich, 2002). Successor auditors of former Andersen clients confront uniquely higher litigation risk and are more conservative about accounting choices. Therefore, abnormal accruals of ex-Anderson companies have significantly dropped after being associated with new auditors (Cahan \& Zhang, 2006). Thus I treat former Anderson clients after the Enron collapse as a special group and expect decreases in compensation for those companies. My first specific hypothesis is:

Hla: The positive relationship between changes in compensation and auditor changes becomes weaker for former Arthur Anderson's clients subsequent to the bankruptcy of Arthur Anderson.

Previous studies suggest that big five accounting firms have better audit quality (Francis \& Wilson, 1988; DeFond, 1992; etc.). Big five auditors are more effective in constraining opportunistic earnings management than non big five auditors, especially when managers desire for income-increasing accrual choices (Francis, Maydew, \& Sparks, 1999; Kim, Chung, \& Firth, 2003). The level of discretionary accruals is significantly lower for big five clients than non-big five clients (Becker, DeFond, Jiambalvo, \& Subramanyam, 1998). Therefore, changes in compensation vary across the successor auditors based on brand names. If the predecessor is a big five auditor and the successor is a non-big five auditor, management is able to inflate net income to a larger magnitude to be offered higher compensation. Otherwise, if the auditor is changed from a non-big five auditor to a big five auditor, management engages in less opportunistic income-increasing activities. My second detailed hypothesis is:

H1b: The positive relationship between changes in compensation and auditor changes becomes stronger (weaker) if the firm switches its auditor from a big five (non-big five) accounting firm to a non-big five (big five) accounting firm.

The compensation-auditor change relationship also relies on which party initiates the switch. Auditor resignations (auditors initiate the change) are tied to high litigation risk and client financial distress (Krishnan \& Krishnan, 1997) and a lack of management integrity (Schroeder \& Verrault, 1987). The capital market reacts negatively to the resignations and the successor auditors are more conservative based on the perceived high audit risk (Wells \& Loudder, 1997). Hence management is less likely to manipulate earnings after the firm finds the successor auditor.

Auditor changes due to accounting disagreements have similar properties to those of auditor resignations. Accounting disagreements aroused from auditor changes reveal that reported earnings are manifested to some degree that might be troublesome (Hackenbrack \& Hogan, 2002). Furthermore, disagreements are related to poor 
financial condition and stock returns are negative prior to auditor changes (Dhaliwal et al., 1993). Thus the successor auditor may be more alert and impose stricter monitoring on management behaviors. My third further hypothesis is:

H1c: The positive relationship between changes in compensation and auditor changes becomes weaker for auditor resignations or audit-client accounting disagreements.

\section{Model Specification}

I establish the equation of compensation based on audit information after controlling economic condition of the company, industries and years. Thus the function about compensation is the following:

Compensation variables $=f$ (auditor change variables, economic variables, industry dummies, year dummies)

There are two measures of compensation variables: cash compensation (CASHCOMP) and total compensation (TOTALCOMP). Total compensation is overall compensation management has earned while cash compensation captures the current component of total compensation.

According to Core et al. (1999), economic variables include natural log of sales (SALES), book to market ratio (BM), return on assets (ROA), one-year stock returns (TRS1YR), standard deviation of ROA (SROA) and standard deviation of one-year stock returns (STRS1YR). SALES is the proxy for firm size and complexity. BM represents the investment opportunity set. ROA and TRS1YR measure the firm performance. SROA and STRS1YR control for firm risk.

Initially, to test $\mathrm{H} 1$, I use $\mathrm{CH}$ as the indicator variable that equals one if the company switches the auditor or equals zero otherwise. The model for testing $\mathrm{H} 1$ is:

$$
\begin{aligned}
& \text { CASHCOMP }_{t} \text { orTOTALCOMP } t=\alpha_{0}+\alpha_{1} \text { CH }_{t-1}+\alpha_{2} \text { SALES }_{t-1}+\alpha_{3} \text { BM }_{t-1}+\alpha_{4} \text { ROA }_{t-1}
\end{aligned}
$$

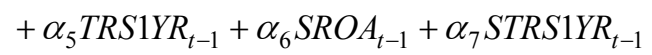

$$
\begin{aligned}
& +\sum \alpha_{j} \text { Industrydummies }_{j}+\sum \alpha_{k} \text { Yeardummies }_{k}+\varepsilon
\end{aligned}
$$

To investigate $\mathrm{H1a}$, I separate $\mathrm{CH}$ into the indicator variables AA (coding one if the predecessor auditor is Arthur Anderson and the fiscal year is after 2001) and NOTAA (coding one for auditor changes other than AA). The equation regarding $\mathrm{H} 1 \mathrm{c}$ is:

$$
\begin{aligned}
\text { CASHCOMP }_{t} \text { orTOTALCOMP }_{t} & =\alpha_{0}+\alpha_{1} \text { AA }_{t-1}+\alpha_{2} \text { NOTAA }_{t-1}+\alpha_{3} \text { SALES }_{t-1} \\
& +\alpha_{4} \text { BM }_{t-1}+\alpha_{5} \text { ROA }_{t-1}+\alpha_{6}{\text { TRS } 1 Y R_{t-1}}_{t}+\alpha_{7} \text { SROA }_{t-1} \\
& +\alpha_{8}{\text { STRS } 1 Y R_{t-1}+\sum \alpha_{j} \text { Industrydummies }_{j}} \\
& +\sum \alpha_{k} \text { Yeardummies }_{k}+\varepsilon
\end{aligned}
$$

Considering H1b, I replace CH with AUD1, AUD2, AUD3. AUD1 codes one for the switch from big five auditors to big five auditors, zero otherwise. AUD2 codes one for the switch from non-big five auditors to big five auditors, zero otherwise. AUD3 codes one for the switch from big five auditors to non-big five auditors, zero otherwise. Thus the intercept term implicitly captures the switch from non-big five auditors to non-big five auditors. The model for testing $\mathrm{H} 1 \mathrm{~b}$ is specified as follows:

$$
\begin{aligned}
& \text { CASHCOMP }_{t} \text { orTOTALCOMP } P_{t}=\alpha_{0}+\alpha_{1} \text { AUD }_{t-1}+\alpha_{2} \text { AUD }_{t-1}+\alpha_{3} A U D 3_{t-1}+\alpha_{4} \text { SALES }_{t-1}
\end{aligned}
$$

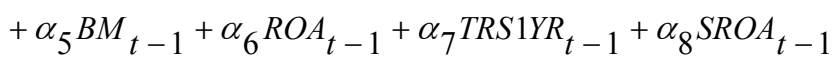

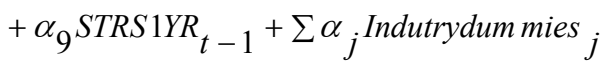

$$
\begin{aligned}
& +\sum \alpha_{k} \text { Yeardummies }_{k}+\varepsilon
\end{aligned}
$$

To examine H1c, I apply the indicator variable RESIGN (equaling one if an auditor resign from the engagement), DISMISS (equaling one if an auditor is dismissed by the client), DISAGREE (equaling one if the dismissal is due to an accounting disagreement), or GO (equaling one if the reason for the dismissal is that the predecessor issues a going concern opinion) to the equation. In addition, the dummy variable AA is put into the equation to control the special case of former Arthur Anderson clients. The models for H1c regarding resignations and disagreements become: 


$$
\begin{aligned}
& \text { CASHCOMP }_{t} \text { orTOTALCOMP }_{t}=\alpha_{0}+\alpha_{1} \text { RESIGN }_{t-1}+\alpha_{2} \text { DISMISS }_{t-1}+\alpha_{3} \text { AA }_{t-1} \\
& +\alpha_{4} S_{A L E S} S_{t-1}+\alpha_{3} B M_{t-1}+\alpha_{4} R O A_{t-1}+\alpha_{5} T_{R S 1 Y R_{t-1}}
\end{aligned}
$$

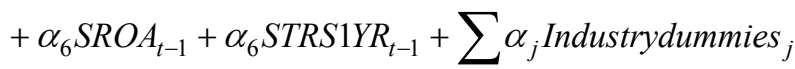

$$
\begin{aligned}
& +\sum \alpha_{k} \text { Yeardummies }_{k}+\varepsilon \\
& \text { CASHCOMP }_{t} \text { orTOTALCOMP }_{t}=\alpha_{0}+\alpha_{1} \text { RESIGN }_{t-1}+\alpha_{2} \text { DISAGREE }_{t-1}+\alpha_{3} \text { GO }_{t-1} \\
& +\alpha_{4} A A_{t-1}+\alpha_{5} \text { SALES }_{t-1}+\alpha_{6} B M_{t-1}+\alpha_{7} R O A_{t-1} \\
& +\alpha_{8} \text { TRS1YR }_{t-1}+\alpha_{9} S R O A_{t-1}+\alpha_{10} S_{T R S 1 Y R_{t-1}} \\
& +\sum \alpha_{j} \text { Industrydummies }_{j}+\sum \alpha_{k} \text { Yeardummies }_{k}+\varepsilon
\end{aligned}
$$

\section{Sample Selection}

My initial sample starts from all available compensation data from the database ExecuComp during the period 1993-2004 (note 2). Since previous studies (Balsam, 1998; Gaver et al., 1995; Holthausen et al., 1995; Gaver et al., 1998) focus on CEO compensation to examine the association of executive compensation with discretionary accounting choices, I also use CEO compensation as the dependent variable. The usage of CEO compensation is optimal because CEOs are ultimately responsible for firm performance and CEOs usually make the decision to manipulate earnings (Gaver et al., 1998). All financial information and information to calculate one-year stock returns is collected from Compustat. Information about auditor names is also gathered from Compustat. Information about types of auditor changes (resignations, dismissals due to accounting disagreements and dismissals due to going concern opinions), and going concern opinions is collected from Audit Analytics. Since the database Audit Analytics only contains audit information from 2000 to 2004, analyses involving information from Audit Analytics are restricted to the period 2000-2004. Thus regressions about Equation 4 and 5 are during 2000-2004.

Table 1. Sample selection

\begin{tabular}{lc}
\hline Selection Criteria & No of observations \\
\hline Obs of CEO total/cash compensation & 18872 \\
Less: Obs without info. on auditor names & 1447 \\
Obs without the financial and stock price data & 4435 \\
Total Observations: & \\
Obs available for the regressions on equations 1 and 2 & 12990 \\
From Total Observations & \\
Less: Obs for companies having switched auditors from Arthur & \\
Anderson to other auditors since 2002 & 259 \\
Obs available for the regression on equations 3 & 12731 \\
From Total Observations & 6921 \\
Less: Obs without info. on auditor resignations or disagreements & 6069 \\
Obs available for the regressions on equation 4 and 5 & \\
\hline
\end{tabular}

Table 1 shows the sample selection process (Panel A, B and C are for the regressions on auditor changes, audit opinions and audit/total fees respectively). Starting with 18,872 observations of available CEO compensation data, I initially exclude 1,447 observations without information on auditor names and 4,435 observations without information on financial or stock price data. Then from the 12,990 observations for regressions on overall auditor changes and on types of auditor changes classified by AA/NOTAA (Equation 1 and 2), I deduct 259 observations, for which AA equals one, to run the regression on types of auditor change classified by brand names (Equation 3) (note 3) and deduct 6,921 observations without information on resignations or disagreements to run the regressions on auditor resignations (Equation 4) and auditor-client disagreements (Equation 5).

To remove the influence of outliers, for the regressions on Equations 1-5, I further delete observations in which 
the absolute value of student's $t$ score is larger than 2. For the regressions of getting residuals from cash / total compensation, I winsorize deflated value of changes in cash / total compensation at the top and bottom $1 \%$.

\section{Frequency Analysis}

Table 2. Frequency of auditor changes

Panel A. Sample period $=1993-2004$

\begin{tabular}{ccccccc}
\hline Frequency & $\begin{array}{c}\text { From Big 5 } \\
\text { to Big 5 }\end{array}$ & $\begin{array}{c}\text { From } \\
\text { Non-big 5 to } \\
\text { Big 5 }\end{array}$ & $\begin{array}{c}\text { From Big 5 } \\
\text { to Non-big 5 }\end{array}$ & $\begin{array}{c}\text { From } \\
\text { Non-big 5 to } \\
\text { Non-big 5 }\end{array}$ & $\begin{array}{c}\text { Auditor } \\
\text { Changes }\end{array}$ & $\begin{array}{c}\text { Non-Auditor } \\
\text { Changes }\end{array}$ \\
\hline 1993 & 2 & 0 & 0 & 0 & 2 & 213 \\
1994 & 11 & 0 & 0 & 0 & 11 & 682 \\
1995 & 29 & 0 & 0 & 0 & 29 & 1134 \\
1996 & 24 & 0 & 1 & 0 & 25 & 1217 \\
1997 & 15 & 0 & 0 & 0 & 15 & 1205 \\
1998 & 29 & 1 & 4 & 0 & 34 & 1201 \\
1999 & 37 & 0 & 12 & 0 & 49 & 1223 \\
2000 & 45 & 2 & 8 & 0 & 55 & 1206 \\
2001 & 37 & 1 & 2 & 0 & 40 & 1232 \\
2002 & 240 & 5 & 7 & 0 & 252 & 1068 \\
2003 & 53 & 3 & 2 & 0 & 58 & 1254 \\
2004 & 21 & 0 & 2 & 0 & 23 & 760 \\
Total & 557 & 13 & 39 & 0 & 609 & 12395 \\
\hline
\end{tabular}

Panel B. Sample period (2000-2004)

\begin{tabular}{cccccc}
\hline Frequency & $\begin{array}{c}\text { Arthur } \\
\text { Anderson is } \\
\text { the predecessor }\end{array}$ & Resignation & Dismissal & $\begin{array}{c}\text { Dismissal due } \\
\text { to the } \\
\text { Disagreement }\end{array}$ & $\begin{array}{c}\text { Dismissal due to } \\
\text { the Going } \\
\text { Concern Opinion }\end{array}$ \\
\hline 2000 & 0 & 1 & 56 & 0 & 1 \\
2001 & 0 & 1 & 41 & 0 & 0 \\
2002 & 234 & 3 & 259 & 2 & 2 \\
2003 & 28 & 5 & 59 & 4 & 2 \\
2004 & 2 & 6 & 22 & 3 & 0 \\
Total & 264 & 16 & 437 & 9 & 5 \\
\hline
\end{tabular}

Table 2 illustrates frequencies of auditor changes. Panel A focuses on the sample period 1993-2004. Overall speaking, observations that companies switch auditors (609) are much fewer than those that companies do not switch auditors $(12,395)$. Companies are most likely to switch auditors from a big 5 accounting firm to another big 5 accounting firm (557 observations). However, no company switches the auditor from a non-big 5 accounting firm to another non-big 5 accounting firm. Considering the partition of auditor changes by years, number of auditor changes roughly increases from 1993 to 2000 and decreases after 2002. Due to the bankruptcy of Arthur Anderson, there is a substantial number of auditor changes in 2002 (252), especially auditor changes from a big 5 auditor to another big 5 auditor (240).

Panel B restricts the sample period to 2000-2004. To sum up, number of resignations (16) is much fewer than number of dismissals (437). Number of disagreement-induced dismissals (9) and number of going-concern-induced dismissals (5) are also very rare. Former Anderson clients mainly seek for other auditors 
in 2002 (234) and rarely do so in 2003 (28) and in 2004 (2). Finally, number of resignations goes up along the years while number of dismissals suddenly dropped in 2004.

\section{Descriptive Statistics}

Table 3. Descriptive statistics

\begin{tabular}{lcccccc}
\hline Variable & Obs & Mean & Std. Dev. & $25 \%$ & Median & $75 \%$ \\
\hline CASHCOMP $_{\mathrm{t}}$ & 12990 & 6.839 & 1.011 & 6.342 & 6.844 & 7.362 \\
TOTALCOMP $_{\mathrm{t}}$ & 12990 & 7.688 & 1.179 & 6.919 & 7.629 & 8.423 \\
MIX $_{\mathrm{t}}$ & 4148 & 0.644 & 0.262 & 0.517 & 0.720 & 0.841 \\
$\mathrm{R}_{\mathrm{t}}$ & 3004 & 0.000 & 0.001 & -0.000 & -0.000 & 0.000 \\
$\mathrm{R}_{\mathrm{t}}$ & 3004 & -0.000 & 0.005 & -0.001 & -0.000 & 0.001 \\
$\mathrm{CH}_{\mathrm{t}-1}$ & 12990 & 0.046 & 0.209 & 0 & 0 & 0 \\
AA $_{\mathrm{t}-1}$ & 12990 & 0.020 & 0.139 & 0 & 0 & 0 \\
NOTAA $_{\mathrm{t}-1}$ & 12990 & 0.026 & 0.159 & 0 & 0 & 0 \\
AUD1 $_{\mathrm{t}-1}$ & 12990 & 0.042 & 0.200 & 0 & 0 & 0 \\
AUD2 $_{\mathrm{t}-1}$ & 12990 & 0.001 & 0.030 & 0 & 0 & 0 \\
AUD3 $_{\mathrm{t}-1}$ & 12990 & 0.003 & 0.054 & 0 & 0 & 0 \\
RESIGN $_{\mathrm{t}-1}$ & 6069 & 0.003 & 0.051 & 0 & 0 & 0 \\
DISMISS $_{\mathrm{t}-1}$ & 6069 & 0.072 & 0.259 & 0 & 0 & 0 \\
DISAGREE $_{\mathrm{t}-1}$ & 6069 & 0.001 & 0.038 & 0 & 0 & 0 \\
SALES $_{\mathrm{t}-1}$ & 12990 & 7.062 & 1.595 & 6.033 & 6.998 & 8.083 \\
BM $_{\mathrm{t}-1}$ & 12990 & 0.521 & 8.827 & 0.258 & 0.426 & 0.645 \\
ROA $_{\mathrm{t}-1}$ & 12990 & 0.052 & 0.162 & 0.020 & 0.054 & 0.100 \\
TRS1YR $_{\mathrm{t}-1}$ & 12990 & 0.219 & 2.476 & -0.140 & 0.094 & 0.363 \\
SROA $_{\mathrm{t}-1}$ & 12990 & 6.451 & 11.407 & 1.924 & 3.521 & 6.483 \\
STRS1YR $_{\mathrm{t}-1}$ & 12990 & 227.614 & 5317.110 & 25.531 & 37.519 & 59.005 \\
CHPMDA $_{\mathrm{t}}$ & 3004 & 0.013 & 3.935 & -0.214 & 0.001 & 0.214 \\
\hline
\end{tabular}

Table 3 provides descriptive statistics for variables in Equation 1-5. For Equations 1 and 2, mean cash compensation and mean total compensation are $\$ 933,555(\exp (6.839) * 1000)$ and $\$ 2,182,006\left(\exp (7.688)^{*} 1000\right)$ respectively. Mean $\mathrm{CH}(0.046)$ and mean AA (0.020) indicate that a very small percentage of observations are associated with auditor changes and among observations of auditor changes, less than half are involved with switches from Arthur Anderson to other auditors after 2001. Mean amount of sales is about $\$ 1.2$ billion $(\exp (7.062) * 1000000)$. Mean ROA of 0.052 and mean TRS1YR of 0.219 imply that the majority of companies earn profits and achieve positive stock returns in one year. For Equation 3, AUD1, AUD2 and AUD3 are 0.004, 0.001 and 0.003 respectively, suggesting that auditor changes mostly happen among big 5 accounting firms. For Equation 4 and 5, RESIGN, DISMISS, DISAGREE and GO are 0.003, 0.072, 0.001 and 0.001 respectively, indicating that there are more dismissals than resignations and that number of dismissals related to accounting disagreements is similar to that related to going concern opinions. 


\section{Regression Results}

Table 4. OLS regressions for auditor changes (sample period $=1993-2004$ )

Panel A. Dependent variables $=\log$ (cash compensation $)_{t}$

\begin{tabular}{|c|c|c|c|c|c|c|}
\hline & \multicolumn{2}{|c|}{ Equation (1) } & \multicolumn{2}{|c|}{ Equation (2) } & \multicolumn{2}{|c|}{ Equation (3) } \\
\hline & Coeff. & t-stat & Coeff. & t-stat & Coeff. & t-stat \\
\hline Intercept & 5.170 & $70.75^{* * *}$ & 5.170 & $70.72^{* * *}$ & 5.178 & $70.37^{* * *}$ \\
\hline $\mathrm{CH}_{\mathrm{t}-1}$ & 0.036 & $1.68^{*}$ & & & & \\
\hline $\mathrm{AUD} 1_{\mathrm{t}-1}$ & & & & & 0.019 & 0.66 \\
\hline $\mathrm{AUD} 2_{\mathrm{t}-1}$ & & & & & -0.041 & -0.24 \\
\hline $\mathrm{AUD}_{\mathrm{t}-1}$ & & & & & 0.254 & $2.94^{* * *}$ \\
\hline $\mathrm{AA}_{\mathrm{t}-1}$ & & & 0.035 & 1.04 & & \\
\hline NOTAA $_{t-1}$ & & & 0.037 & 1.34 & & \\
\hline SALES $_{\mathrm{t}-1}$ & 0.319 & $99.64^{* * *}$ & 0.319 & $99.64^{* * *}$ & 0.318 & $98.71^{* * *}$ \\
\hline $\mathrm{BM}_{\mathrm{t}-1}$ & -0.001 & -1.35 & -0.001 & -1.35 & -0.001 & -1.35 \\
\hline $\mathrm{ROA}_{\mathrm{t}-1}$ & 0.019 & 0.63 & 0.019 & 0.63 & 0.022 & 0.71 \\
\hline $\mathrm{TRS}_{1} \mathrm{YR}_{\mathrm{t}-1}$ & 0.032 & $8.60^{* * *}$ & 0.032 & $8.60^{* * *}$ & 0.032 & $8.46^{* * *}$ \\
\hline $\mathrm{SROA}_{\mathrm{t}-1}$ & -0.000 & -0.34 & -0.000 & -0.34 & -0.000 & -0.26 \\
\hline $\mathrm{STRS}_{1 \mathrm{YR}_{\mathrm{t}-1}}$ & 0.000 & $5.58^{* * *}$ & 0.000 & $5.58^{* * *}$ & 0.000 & $5.58^{* * *}$ \\
\hline Obs & \multicolumn{2}{|c|}{12804} & \multicolumn{2}{|c|}{12804} & \multicolumn{2}{|c|}{12551} \\
\hline Adj. $\mathrm{R}^{2}$ & \multicolumn{2}{|c|}{$55.62 \%$} & \multicolumn{2}{|c|}{$55.61 \%$} & \multicolumn{2}{|c|}{$55.73 \%$} \\
\hline
\end{tabular}

Panel B. Dependent variables $=\log (\text { total compensation })_{t}$

\begin{tabular}{|c|c|c|c|c|c|c|}
\hline & \multicolumn{2}{|c|}{ Equation (1) } & \multicolumn{2}{|c|}{ Equation (2) } & \multicolumn{2}{|c|}{ Equation (3) } \\
\hline & Coeff. & t-stat & Coeff. & t-stat & Coeff. & t-stat \\
\hline Intercept & 5.070 & $46.47^{* * *}$ & 5.071 & $46.44^{* * *}$ & 5.089 & $46.14^{* * *}$ \\
\hline $\mathrm{CH}_{\mathrm{t}-1}$ & -0.015 & -0.51 & & & & \\
\hline $\mathrm{AUD}_{\mathrm{t}-1}$ & & & & & -0.024 & -0.59 \\
\hline $\mathrm{AUD} 2_{\mathrm{t}-1}$ & & & & & -0.514 & $-1.93^{*}$ \\
\hline$A U D 3_{t-1}$ & & & & & 0.034 & 0.125 \\
\hline $\mathrm{AA}_{\mathrm{t}-1}$ & & & 0.003 & 0.05 & & \\
\hline NOTAA $_{t-1}$ & & & -0.028 & -0.71 & & \\
\hline SALES $_{\mathrm{t}-1}$ & 0.442 & $95.08^{* * *}$ & 0.442 & $94.96^{* * *}$ & 0.440 & $93.64^{* * *}$ \\
\hline $\mathrm{BM}_{\mathrm{t}-1}$ & -0.006 & $-3.94^{* * *}$ & -0.006 & $-3.93^{* * *}$ & -0.006 & $-3.87^{* * *}$ \\
\hline $\mathrm{ROA}_{\mathrm{t}-1}$ & 0.152 & $3.23^{* * *}$ & 0.152 & $3.21^{* * *}$ & 0.150 & $3.15^{* * *}$ \\
\hline $\mathrm{TRS}_{1 \mathrm{YR}_{\mathrm{t}-1}}$ & 0.153 & $15.43^{* * *}$ & 0.153 & $15.43^{* * *}$ & 0.155 & $15.46^{* * *}$ \\
\hline $\mathrm{SROA}_{\mathrm{t}-1}$ & 0.009 & $12.17^{* * *}$ & 0.009 & $12.17^{* * *}$ & 0.009 & $12.04^{* * *}$ \\
\hline $\mathrm{STRS}_{1} \mathrm{YR}_{\mathrm{t}-1}$ & 0.000 & $5.65^{* * *}$ & 0.000 & $5.66^{* * *}$ & 0.000 & $5.62^{* * *}$ \\
\hline Obs & \multicolumn{2}{|c|}{12489} & \multicolumn{2}{|c|}{12491} & \multicolumn{2}{|c|}{12249} \\
\hline Adj. $R^{2}$ & \multicolumn{2}{|c|}{$53.18 \%$} & \multicolumn{2}{|c|}{$53.16 \%$} & \multicolumn{2}{|c|}{$53.01 \%$} \\
\hline
\end{tabular}

$* * *, * *, *$ Coefficient is significant at the one percent level, the five percent level, the ten percent level respectively (one-tailed where signs are predicted, two-tailed otherwise). 
Table 4 summarizes the regressions results for Equations 1-3 during the sample period 1993-2004. Panel A presents results when natural log of cash compensation is the dependent variable. Regarding the financial and stock market variables, coefficients on SALES, TRS1YR, and STRS1YR are positively significant for all three equations, suggesting that firm size, prior performance and firm risk are positively related to cash compensation. The results are partially consistent with those of Core et al. (1993) since Core et al. (1993) find that SALES, BM, TRS1YR and SROA have the explanatory power. In the regression for equation $1, \mathrm{CH}$ has the positive coefficient of 0.036 that is significant at the $10 \%$ level (t-statistics $=1.68)$. This supports H1 that the occurrence of auditor changes increases CEO compensation. In particular, cash compensation of a CEO is approximately $4 \%$ $(\exp (0.036)-1)$ higher after switching the auditor. In the regression for Equation 2, none of coefficients on AA and NOTAA is significant, indicating that there is no difference in cash compensation whether the CEO works for a former Anderson client or not. Thus H1a is not supported. In the regression for Equation 3, among three indicator variables of AUD1, AUD2 and AUD3, only coefficient on AUD3 is positive and significant at the 1\% percent level $(0.254$, t-statistics $=2.94)$. This confirms H1b and implies that the change from big 5 auditors to non-big 5 auditors actually produces the positive association of cash compensation with auditor changes. Specifically, the switches from big 5 auditors to non-big 5 auditors increase cash compensation by almost $30 \%$ $(\exp (0.254)-1)$.

Panel B shows results for regressions whose dependent variable is natural log of total compensation. For all three equations, all financial and stock market variables (SALES, BM, ROA, TRS1YR, SROA and STRS1YR) have significant coefficients. The results are even stronger than those of Core et al. (1993). The exception from results of Core et al. (1993) is that the coefficient on BM is negative. In terms of dummy variables of auditor changes in Equation 1-3, results are similar to those from Panel A except results in Equation 1. For Equation 1, coefficient on $\mathrm{CH}$ becomes insignificant, suggesting that the incidence of auditor change has no impact on total compensation. Therefore, empirical evidence regarding $\mathrm{H} 1$ is not consistent and we need to look at results from regressions on the partition of auditor changes. For Equation 2, both AA and NOTAA do not have significant coefficients. For Equation 3, AUD2 has the negative and significant coefficient. This indicates that the switch from a non-big 5 auditor to a big 5 auditor decreases total compensation. Actually total compensation is reduced by about $40 \%(1-\exp (-0.514))$ after the switch. The result also supports H1b because the negative relationship between total compensation and the non-big-5-to-big-5 auditor changes is the extreme case to dampen the positive association of compensation with auditor changes.

Table 5. OLS regressions for auditor resignations or disagreements (sample period $=2000-2004$ )

Panel A. Dependent variables $=\log (\text { cash compensation })_{t}$

\begin{tabular}{|c|c|c|c|c|}
\hline & \multicolumn{2}{|c|}{ Equation (4) } & \multicolumn{2}{|c|}{ Equation (5) } \\
\hline & Coeff. & t-stat & Coeff. & t-stat \\
\hline Intercept & 5.183 & $44.70^{* * *}$ & 5.187 & $44.75^{* * *}$ \\
\hline RESIGN $_{\mathrm{t}-1}$ & -0.225 & $-1.65^{*}$ & -0.220 & -1.51 \\
\hline DISMISS $_{\mathrm{t}-1}$ & 0.042 & 1.04 & & \\
\hline DISAGREE $_{\mathrm{t}-1}$ & & & -0.141 & -0.74 \\
\hline $\mathrm{GO}_{\mathrm{t}-1}$ & & & 0.343 & 0.89 \\
\hline $\mathrm{AA}_{\mathrm{t}-1}$ & -0.033 & -0.62 & 0.008 & 0.22 \\
\hline SALES $_{\mathrm{t}-1}$ & 0.320 & $63.21^{* * *}$ & 0.320 & $63.21^{* * *}$ \\
\hline $\mathrm{BM}_{\mathrm{t}-1}$ & -0.000 & -0.95 & -0.000 & -0.95 \\
\hline $\mathrm{ROA}_{\mathrm{t}-1}$ & 0.050 & 1.31 & 0.050 & 1.29 \\
\hline $\mathrm{TRS}_{1} \mathrm{YR}_{\mathrm{t}-1}$ & 0.022 & $5.24^{* * *}$ & 0.022 & $5.24^{* * *}$ \\
\hline $\mathrm{SROA}_{\mathrm{t}-1}$ & 0.001 & 0.80 & 0.001 & 0.80 \\
\hline STRS1YR ${ }_{t-1}$ & 0.000 & 0.99 & 0.000 & 0.98 \\
\hline Obs & \multicolumn{2}{|c|}{5875} & \multicolumn{2}{|c|}{5875} \\
\hline Adj. $R^{2}$ & \multicolumn{2}{|c|}{$54.87 \%$} & \multicolumn{2}{|c|}{$54.86 \%$} \\
\hline
\end{tabular}


Panel B. Dependent variables $=\log (\text { total compensation })_{t}$

\begin{tabular}{|c|c|c|c|c|}
\hline & \multicolumn{2}{|c|}{ Equation (4) } & \multicolumn{2}{|c|}{ Equation (5) } \\
\hline & Coeff. & t-stat & Coeff. & t-stat \\
\hline Intercept & 4.528 & $26.33^{* * *}$ & 4.475 & $26.15^{* * *}$ \\
\hline RESIGN $_{\mathrm{t}-1}$ & -0.131 & -0.66 & -0.033 & -0.16 \\
\hline DISMISS $_{\mathrm{t}-1}$ & -0.085 & -1.43 & & \\
\hline DISAGREE $_{\mathrm{t}-1}$ & & & -0.177 & -0.64 \\
\hline $\mathrm{GO}_{\mathrm{t}-1}$ & & & 0.091 & 0.16 \\
\hline $\mathrm{AA}_{\mathrm{t}-1}$ & 0.057 & 0.73 & -0.031 & -0.59 \\
\hline SALES $_{\mathrm{t}-1}$ & 0.472 & $62.83^{* * *}$ & 0.476 & $63.60^{* * *}$ \\
\hline $\mathrm{BM}_{\mathrm{t}-1}$ & -0.005 & $-3.09^{* * *}$ & -0.006 & $-2.01^{* *}$ \\
\hline $\mathrm{ROA}_{\mathrm{t}-1}$ & 0.487 & $6.09^{* * *}$ & 0.416 & $5.19^{* * *}$ \\
\hline $\mathrm{TRS}_{\mathrm{Y}} \mathrm{YR}_{\mathrm{t}-1}$ & 0.026 & $4.20^{* * *}$ & 0.113 & $9.18^{* * *}$ \\
\hline $\mathrm{SROA}_{\mathrm{t}-1}$ & 0.010 & $9.24^{* * *}$ & 0.010 & $8.89^{* * *}$ \\
\hline STRS1YR t-1 $_{1}$ & 0.000 & $2.12^{* *}$ & 0.000 & $2.13^{* *}$ \\
\hline Obs & \multicolumn{2}{|c|}{5875} & \multicolumn{2}{|c|}{5750} \\
\hline Adj. $R^{2}$ & \multicolumn{2}{|c|}{$49.20 \%$} & \multicolumn{2}{|c|}{$49.73 \%$} \\
\hline
\end{tabular}

***,**, Coefficient is significant at the one percent level, the five percent level, the ten percent level respectively (one-tailed where signs are predicted, two-tailed otherwise).

Table 5 provides the regression results for Equations 4 and 5 during the sample period 2000-2004. Panel A is for cash compensation and Panel B is for total compensation. Considering financial and stock market variables in Panel A and B, variables capable of affecting cash compensation are SALES and STRS1YR while all variables are able to predict total compensation. In Equation 4 of Panel A, the negative coefficient on RESIGN indicates that a CEO receives less cash compensation after the auditor resigns from the engagement. However, RESIGN turns into insignificant in Equation 4 of Panel B. Hence the prediction of the compensation-resignation relationship in H1c is not completely supported. In addition, tcoefficient on DISAGREE is not significant in both Panel A and Panel B. Thus there is no relation between CEO compensation and dismissals that are related to accounting disagreements. To sum up, there is very weak evidence to confirm H1c. One reason to explain the lack of evidence is that there are very few observations of resignations and disagreement-related dismissals.

\section{Conclusions}

This study investigates the ability of auditors when auditors function as the outside control mechanism to monitor management opportunistic behaviors. I examine the efficiency of auditors' monitoring role through variations of CEO compensation when there are changes in auditors during the sample period 1993-2004. Due to data limitation, the sample period is restricted to 2000-2004 when I explore impacts of specific auditor changes (resignations and accounting disagreements).

The frequency analysis shows that most companies do not want to switch auditors. Auditors are also reluctant to resign from the engagement or file accounting disagreements to the public. However, due to the bankruptcy of Arthur Anderson, in 2002 there is a large number of mandatory auditor switches, especially the switches from Arthur Anderson to other big 5 auditors. The multivariate analysis about auditor switches implies that in general, auditors are not the good external control mechanism to deter opportunistic behaviors of management to overstate earnings. After auditor switches, especially the switches from big 5 auditors to non-big 5 auditors, CEOs are able to manipulate earnings to receive higher compensation. In particular, CEO cash compensation is $30 \%$ higher after companies change auditors from big 5 auditors to non-big 5 auditors. However, since big 5 auditors impose stricter requirements on clients than non-big 5 auditors, CEOs have fewer opportunities to manipulate earnings and thus receive $40 \%$ less total compensation after switching auditors from non-big 5 auditors to big 5 auditors. 


\section{Reference}

Antle, R., \& Nalebuff, B. (1991). Conservatism and auditor-client negotiations. Journal of Accounting Research, 29(Supplement), 31-54. http://dx.doi.org/10.2307/2491002

Balsam, S. (1998). Discretionary accounting choices and CEO compensation. Contemporary Accounting Research, 15(Fall), 229-252. http://dx.doi.org/10.1111/j.1911-3846.1998.tb00558.x

Becker, C., DeFond, M., Jiambalvo, J., \& Subramanyam, K. (1998). The effect of audit quality on earnings management. Contemporary Accounting Research, 15(Spring), 1-24. http://dx.doi.org/10.1111/j.1911-3846.1998.tb00547.x

Bergstresser, D., \& Philippon, T. (2004). CEO incentives and earnings management. Working paper. Harvard University and New York University.

Bradshaw, M., Richardson, S., \& Sloan, R. (2001). Do analysts and auditors use information in accruals? Journal of Accounting Research, 39(June), 45-74. http://dx.doi.org/10.1111/1475-679X.00003

Cahan, S., \& Zhang, W. (2006). After enron: Auditor conservatism and ex-andersen clients. The Accounting Review, 81(January), 49-82. http://dx.doi.org/10.2308/accr.2006.81.1.49

Chaney, P., \& Philipich, K. (2002). Shredded reputation: The cost of audit failure. Journal of Accounting Research, 40(September), 1221-1245. http://dx.doi.org/10.1111/1475-679X.00087

Chen, C., Krishnan, G., \& Su, X. (2002). The association between non-audit service purchases and managers' compensation structure. Working paper, City University of Hong Kong, Hong Kong.

Core, J., Holthausen, R., \& Larcker, D. (1999). Corporate governance, chief executive officer compensation, and firm performance. Journal of Financial Economics, 51, 371-406. http://dx.doi.org/10.1016/S0304-405X(98)00058-0

Davila, A., \& Penalva, F. (2004). Corporate governance and the weighting of performance measures in CEO compensation. Working Paper. University of Navarra, Spain.

DeFond, M. (1992). The association between changes in client firm agency costs and auditor switching. Auditing: A Journal of Practice and Theory, 11(Spring), 16-31.

DeFond, M., \& Jiambalvo, J. (1993). Factors related to auditor-client disagreements over income-increasing accounting methods. Contemporary Accounting Research, 9(Spring), 415-431. http://dx.doi.org/10.1111/j.1911-3846.1993.tb00889.x

DeFond, M., \& Subramanyam, K. (1998). Auditor Changes and Discretionary Accruals. Journal of Accounting and Economics, 25, 35-67. http://dx.doi.org/10.1016/S0165-4101(98)00018-4

Dhaliwal, D., Schatzberg, J., \& Trombley, M. (1993). An analysis of the economic factors related to auditor-client disagreements preceding auditor changes. Auditing: A Journal of Practice and Theory, 12(Fall), 22-38.

Francis, J., \& Wilson, E. (1988). Auditor changes: A joint test of theories relating to agency costs and auditor differentiation. The Accounting Review, 63(October), 663-681.

Francis, J., Maydew, E., \& Sparks, H. (1999). The role of big 6 auditors in the credible reporting of accruals. Auditing: A Journal of Practice \& Theory, 18(Fall), 17-34. http://dx.doi.org/10.2308/aud.1999.18.2.17

Frankel, R., Johnson, M., \& Nelson, K. (2002). The relation between auditors' fees for nonaudit services and earnings management. The Accounting Review, 77(Supplement), 71-105. http://dx.doi.org/10.2308/accr.2002.77.s-1.71

Gaver, J., \& Gaver, K. (1998). The relation between nonrecurring accounting transactions and CEO cash compensation. The Accounting Review, 73(April), 235-253.

Gaver, J., Gaver, K., \& Austin, J. (1995). Additional evidence on bonus plans and income management. Journal of Accounting and Economics, 19, 3-28. http://dx.doi.org/10.1016/0165-4101(94)00358-C

Gibbins, M., Salterio, S., \& Webb, A. (2001). Evidence about auditor-client management negotiation concerning client's financial reporting. Journal of Accounting Research, 39(December), 535-563. http://dx.doi.org/10.1111/1475-679X.00027

Hackenbrack, K., \& Hogan, C. (2002). Market response to earnings surprises conditional on reasons for an auditor changes. Contemporary Accounting Research, 19(Summer), 195-223. 


\section{http://dx.doi.org/10.1506/5XW7-9CY6-LLJY-BA2F}

Hackenbrack, K., \& Nelson, M. (1996). Auditors' incentives and their application of financial accounting standards. The Accounting Review, 71(January), 43-59.

Harvey, K., \& Shrieves, R. (2001). Executive compensation structure and corporate governance choices. The Journal of Financial Research, 4(Winter), 495-512.

Holmstrom, B. (1979). Moral hazard and observability. Bell Journal of Economics, (Spring), 74-91. http://dx.doi.org/10.2307/3003320

Holthausen, R., Larcker, D., \& Sloan, R. (1995). Annual bonus schemes and the manipulation of earnings. Journal of Accounting and Economics, 19, 29-74. http://dx.doi.org/10.1016/0165-4101(94)00376-G

Jensen, M., \& Meckling, W. (1976). Theory of the firm: Managerial behavior, agency costs and ownership structure. Journal of Financial Economics, 3, 305-360. http://dx.doi.org/10.1016/0304-405X(76)90026-X

Kim, J., Chung, R., \& Firth, M. (2003). Auditor conservatism, asymmetric monitoring, and earnings management. Contemporary Accounting Research, 20(Summer), 323-359. http://dx.doi.org/10.1506/J29K-MRUA-0APP-YJ6V

Krishnan, J. (1994). Auditor switching and conservatism. The Accounting Review, 69(January), 200-215.

Krishnan, J., \& Krishnan, J. (1997). Litigation risk and auditor resignations. The Accounting Review, 72(October), $539-560$.

Krishnan, J., \& Ye, Z. (2005). Why some companies seek shareholder ratification on auditor selection. Accounting Horizons, 19(December), 237-254. http://dx.doi.org/10.2308/acch.2005.19.4.237

Lennox, C. (2005). Audit quality and executive officers' affiliations with CPA firms. Journal of Accounting and Economics, 39(June), 201-231. http://dx.doi.org/10.1016/j.jacceco.2003.12.002

Menon, K., \& Williams, D. (2004). Former audit partners and abnormal accruals. The Accounting Review, 79, 1095-1118. http://dx.doi.org/10.2308/accr.2004.79.4.1095

Mutchler, J., Hopwood, W., \& McKeown, J. (1997). The influence of contrary information and mitigating factors on audit opinion decisions on bankrupt companies. Journal of Accounting Research, 35(Autumn), 295-310. http://dx.doi.org/10.2307/2491367

Public Oversight Board. (2003). Directors, management, auditors-allies in protecting shareholder interests. Special report.

Raghunandan, K. (2003). Nonaudit services and shareholder ratification of auditors. Auditing: A Journal of Practice \& Theory, 22(March), 155-163. http://dx.doi.org/10.2308/aud.2003.22.1.155

Raghunandan, K., \& Rama, D. (2003). Audit committee composition and shareholders voting on auditor ratification. Auditing: A Journal of Practice \& Theory, 22(September), 253-263. http://dx.doi.org/10.2308/aud.2003.22.2.253

Roberts, R., Glezen, G., \& Jones, T. (1990). Determinants of auditor change in the public sector. Journal of Accounting Research, 28(Spring), 220-228. http://dx.doi.org/10.2307/2491226

Schroeder, R., \& Verrault, K. (1987). An empirical analysis of auditor withdrawal decisions. Advances in Accounting, 5, 205-220.

Wallace, W. (1987). The economic role of the audit in free and regulated markets: A review. Research in Accounting Regulation, 1, 7-34.

Wells, D., \& Loudder, M. (1997). The market effects of auditor resignations. Auditing: A Journal of Practice \& Theory, 16(Spring), 138-144.

Zimbleman, M., \& Waller, W. (1999). An experimental investigation of auditor-auditee interaction under ambiguity. Journal of Accounting Research, 37(Supplement), 135-155. http://dx.doi.org/10.2307/2491349

\section{Notes}

Note 1. Raghunandan and Rama (2003) record a mean rejection rate of 1.48 percent in 2001.

Note 2. Compensation data in 1992 is deleted because I need the data about economic conditions one year prior to the compensation data.

Note 3. I deleted observations for AA because the reason for companies to switch from Arthur Anderson to other 
auditors after 2001 is different from reasons of other auditor switches based on auditor names.

\section{Appendix}

Appendix 1. Definition of variables

\begin{tabular}{|c|c|}
\hline CAS & atural log of cash compensation (salary and bonus) of the CEO \\
\hline TOTALCOMP $_{\mathrm{t}}$ & $\begin{aligned}= & \text { Natural log of total compensation (including salary, bonus, other annual compensation, all other total } \\
& \text { compensation with option grants) of the CEO in year } t\end{aligned}$ \\
\hline MIX $_{\mathrm{t}}$ & rrent incentive compensation to total compensation \\
\hline $\mathrm{R} 1_{\mathrm{t}}$ & $\begin{aligned}= & \text { Residual from the regression of cash compensation (deflated by total assets) in year } \mathrm{t} \text { on sales } \\
& \text { (deflated by total assets) in year } \mathrm{t}-1, \mathrm{BM}_{\mathrm{t}-1, \mathrm{ROA}_{\mathrm{t}-1}, \mathrm{TRS}_{\mathrm{YYR}} \mathrm{t}-1, \mathrm{SROA}_{\mathrm{t}-1,} \text {, and STRS1YR }} \mathrm{ST}_{\mathrm{t}}\end{aligned}$ \\
\hline $\mathrm{R} 2_{\mathrm{t}}$ & $\begin{aligned}= & \text { Residual from the regression of total compensation (deflated by total assets) in year } \mathrm{t} \text { on sales } \\
& \text { (deflated by total assets) in year } \mathrm{t}-1, \mathrm{BM}_{\mathrm{t}-1}, \mathrm{ROA}_{\mathrm{t}-1}, \mathrm{TRS}_{\mathrm{Y}} \mathrm{YR}_{\mathrm{t}-1}, \mathrm{SROA}_{\mathrm{t}-1} \text {, and STRS1YR } \mathrm{t}-1\end{aligned}$ \\
\hline $\mathrm{CH}_{\mathrm{t}-1}$ & $=1$ if the company switches the auditor in year $\mathrm{t}-1$ and 0 otherwise \\
\hline $\mathrm{AA}_{\mathrm{t}-1}$ & $\begin{array}{l}=1 \text { if the company switches its predecessor auditor of Arthur Anderson to any other auditor in year t- } 1 \\
\text { after } 2001 \text { and } 0 \text { otherwise }\end{array}$ \\
\hline NOTAA $_{t-1}$ & $\begin{array}{c}=1 \text { if the company switches its auditor in year t- } 1 \text { before } 2002 \text { or the company switches its auditor in } \\
\text { year } \mathrm{t}-1 \text { after } 2001 \text { but the predecessor auditor is not Arthur Anderson, and } 0 \text { otherwise }\end{array}$ \\
\hline $\mathrm{AUD}_{\mathrm{t}-1}$ & $\begin{array}{l}=1 \text { if the company changes its auditor from a big } 5 \text { accounting firm to another big } 5 \text { accounting firm in } \\
\text { year } t-1 \text { and } 0 \text { otherwise }\end{array}$ \\
\hline $\mathrm{AUD} 2_{\mathrm{t}-1}$ & $\begin{array}{l}=1 \text { if the company changes its auditor from a non-big } 5 \text { accounting firm to a big } 5 \text { accounting firm in } \\
\text { year } \mathrm{t}-1 \text { and } 0 \text { otherwise }\end{array}$ \\
\hline $\mathrm{AUD} 3_{\mathrm{t}-1}$ & $\begin{array}{l}=1 \text { if the company changes its auditor from a big } 5 \text { accounting firm to a non-big } 5 \text { accounting in year } \\
\text { t- } 1 \text { and } 0 \text { otherwise }\end{array}$ \\
\hline RESIGN $_{\mathrm{t}-1}$ & $=1$ if the auditor resigns from the engagement in year $t-1$ and 0 otherwise \\
\hline DISMISS $_{\mathrm{t}-1}$ & $=1$ if the company dismisses its auditor in year t- 1 and 0 otherwise \\
\hline DISAGREE $_{\mathrm{t}-1}$ & $=1$ if the dismissal in year $\mathrm{t}-1$ is due to the accounting disagreement and 0 othe \\
\hline SALES $_{\mathrm{t}-1}$ & $=$ Natural log of sales in year $\mathrm{t}-1$ \\
\hline $\mathrm{BM}_{\mathrm{t}-1}$ & $\begin{aligned}= & \text { The ratio of common equity (Compustat data } \# 60 \text { ) in year } \mathrm{t}-1 \text { to the market value (Compustat data \#25 } \\
& \times \text { Compustat data \#199) at fiscal year end } \mathrm{t}-1\end{aligned}$ \\
\hline $\mathrm{ROA}_{\mathrm{t}-1}$ & $\begin{aligned}= & \text { Net income before extraordinary items (Compustat data \#18) in year } \mathrm{t}-1 \text {, deflated by total assets } \\
& (\text { Compustat data \#6) at beginning of fiscal year } \mathrm{t}-1\end{aligned}$ \\
\hline TRS1YR $_{\mathrm{t}-1}$ & $\begin{aligned}= & \text { Adjusted stock price (Compustat data } \# 199 \text { / Compustat data \#27) in year t-1 plus adjusted dividend } \\
& \text { (Compustat data } \# 26 \text { / Compustat dat \#27) minus adjusted stock price at beginning of fiscal year t-1, } \\
& \text { deflated by adjusted stock price at beginning of fiscal year t-1 }\end{aligned}$ \\
\hline $\mathrm{SROA}_{\mathrm{t}-1}$ & $=$ Standard deviation of ROA in year $\mathrm{t}-1$ \\
\hline STRS1YR $\mathrm{H}_{\mathrm{t}-1}$ & $=$ Standard deviation of one-year stock returns in year t-1 \\
\hline CHPMDA $_{t}$ & Changes in performance-matched discretionary accruals in year $\mathrm{t}$, deflated by total assets in year $\mathrm{t}$ \\
\hline
\end{tabular}

\section{Copyrights}

Copyright for this article is retained by the author(s), with first publication rights granted to the journal.

This is an open-access article distributed under the terms and conditions of the Creative Commons Attribution license (http://creativecommons.org/licenses/by/3.0/). 